\title{
Organisational Effectiveness and Customer Satisfaction
}

\author{
Milan Ambrož', Martina Praprotnik ${ }^{2}$ \\ ${ }^{1}$ Institut za samorazvoj d.o.o., Kidričeva 75a, 4220 Škofja Loka, Slovenija, ambrozmilan@siol.net \\ ${ }^{2}$ Kropa 95, 4245 Kropa, Slovenija, martina_praprotnik@yahoo.com
}

This paper presents a test of the relationship between organizational culture as a crucial indicator of organizational effectiveness and customer satisfaction using service-unit data from two health resorts. Ensuring survival of the service organisation in the long run requires adaptations which are oriented towards achieving maximum customer satisfaction. This study intended to unveil the effect organisational factors have on customer service orientation from the customer and employee point of view within a two health resort service setting. The finding suggests that when trying to predict the comparative degree which organisational effectiveness factors have in satisfying customers' needs, performance, adaptability and mission can be of the highest importance. Some effects like performance were uniform for employees and customers, while others varied depending on the organisation and the customer or employee group. Furthermore, findings suggest that service performance and organisation mission of the service organisation predict customer satisfaction based on established and proven health services. In this context there is no room for innovation, despite the fact that employees and customers do not share similar views about the impact of organisational effectiveness. Developing an effective service organisation can provide a competitive advantage to the organisation. Critical for the success of the service organisation is that organisational agents have a clear view of the existing organisation effectiveness and a clear view of the customer expectations in this area.

Key words: organisational effectiveness, customer satisfaction, customer complexity, service orientation, survival, adaptability

\section{Introduction}

Health resort organisations are the providers of the most complex services, because they commonly act as service provider and producer of goods at the same time. The difficulty of this complexity shows a need to improve organisational effectiveness to become more competitive in the health service market. As in many other private and public service organisations, competitive advantage is strongly attached to and dependent upon customer satisfaction. Customers and consumers put high pressure on service organisations to provide and deliver a cheap, innovative and high quality service. They develop new needs and expectations which directly push service organisations to compete and strengthen their capability to satisfy the customer. These rapid changes are happening due to development of the information society. The customer is well-informed, goal-oriented and wants to participate actively in the process of creation and consummation of the service to expand the field of his satisfaction. Moreover, new customers have access to similar services at the same time and a possibility to benchmark the service of one provider to the services of other pro- viders. Bellou (2007) estimates that the new customer has the power to decide which organisation will survive and which organisation will eventually cease to exist. Such a competitive environment pushes service organisations to search for new and innovative ways to satisfy customers as well as new factors of organisational effectiveness. It is of the utmost importance that an organisation understand its competitive advantages and its position in the market based on a clear mission. It is not enough to provide a customer with a contracted service. Service organisations deliver service timely and effectively accompanied with feelings of comfort and joy, and the possibility of customer inclusion in the service that he or she wants to buy. These new demands can be fulfilled when a service organisation has a customer oriented organisational culture, which is in a constant flux of innovation.

The aim of our study is to gain insight into the relationship between organisational effectiveness and customer satisfaction from the employee and the customer point of view in two health resort service organisations. The study tries to reveal how existing organisational effectiveness in these two organisations shapes the organisation and its ability to emphasise customer needs and priorities (Heiser, McQuitty and Stratemeyer, 2005). 


\section{Theory and implications}

\subsection{The relationship between organizational culture and organisational effectiveness}

Organizational culture is defined as a system of common beliefs, values, norms and rules in an organisation that conduct the behaviour and emotions of its members (Schein, 1995). It is manifested in the way that organisations' members work, perform tasks and in the way that decisions about important concerns of the organization are expressed. It articulates the organisations' policy, strategy and procedures. Among other things it gives meaning to the success and creates a unique picture of the organisational environment (Hofstede, 1981). Common, and at the same time divided images of an organisation, articulated by common beliefs, creates a unique organisational style. It is the image of the way that an organisation and its customers, partners and stakeholders understand, resonate and value its performance (Hofstede, 2006; Hatch and Cunliffe, 2006, Schein, 2005; O’Donovan, 2006).

Many studies show that organizational culture is one of the most important factors with an influential role in the determination of organizational performance (Chatman and John, 1994, Hofstede et al, 1990, Schein, 1990, Denison, 1990, Fey and Denison, 2003, Gillespie et al, 2007). Lewis (2002) even argues that organizational culture has proven to be an enduring concept in predicting performance.

Additionally, many researchers have confirmed the relationship between organisational culture and effectiveness (Denison, 1990; Ambrož, 2004; Ouchi, 1981; Kwantes and Boglarsky, 2007; Berry and Parasuraman, 1992; Stein and Bowen, 2003). A number of authors have investigated culture from a strategic perspective and have presented culture as a source of competitive advantage (Wilkins and Ouchi, 1983; O’Neill et al, 2001; Hasmi and Asaari, 2007). Detert (2000) focused organisational researchers on the relation between the organisational culture and quality of services. His research shows that there is a close relationship between a quality service system and organisational culture.

Denison (1990), Kotter and Hesket (1992), Denison and Mishra (1995) developed explicit theories of organizational culture and effectiveness, but have focused on the American context. Hofstede (1980), Conrad (1997) and Fey and Denison (2000) related organizational culture to different national contexts and showed that organizational culture cannot be studied as a distinctive phenomenon.

Gilbert and Parhizgari (2000) investigated service organizations and found that different service organization cultures are effective in different contexts. Ambrož (2004) researched the relationship between organizational culture and performance in three industrial organizations and confirmed that their culture distinctively and uniquely affected their performance. It has been recently firmly asserted that organisational culture is effective only in certain circumstances (Igo and Skitmore, 2006). Trice and Beyer (1993: 174) caution that although organiza- tions may have distinctive cultures, it would not be wise to consider that an organization has a single, homogeneous culture.

They argue that various scholars have commented that most organisations have multiple cultures embedded within an encompassing or complete culture that are labelled as subcultures (Ouchi, 1980; Ashforth and Mael, 1989). Subgroups in organizations can create subcultures that build specific networks of meaning and at the same time remain associated with the ideologies and values of the organization's leadership (Bellou, 2007). The fact that the impact of cultures and subcultures differs in predicting an organization's performance leads us to an investigation of the relationship between the perceptions of the role of the organizational culture of the employees and the customers of the particular organization. Parasuraman et al. (1985) suggest that employees can predict customer perceptions of many determinants of service quality. They are particularly accurate in service quality areas such as courtesy and responsiveness.

Schneider, Parkington \& Buxton (1980) and Schneider and Bowen (1985) revealed that branch customer attitudes about service quality were significantly correlated to employee views of customer service. Furthermore, Conduit and Mavondo (2001) found that synergistic effects of an internal customer orientation and market orientation have an impact on an organization's performance. Subramony, Beehr and Johnson (2004) investigated employee and customer perceptions on service effectiveness, group maturity, and service quality and confirmed positive links between these two group's perceptions. However, other studies do not support their conclusions. A study by Shahani-Denning (2000) revealed that customers and employees often perceive organizational effectiveness differently. Recently there has been an urgent need to study the relationship between an organization's behaviours and customer satisfaction. Despite the fact that profit is the major goal of every organization, most research efforts are spent on customer satisfaction and on his or her experiences with a service organization (Anderson et al., 1997). Bowen et al (2000) and Gupta et al (2005) studied organisational culture and customer satisfaction and confirmed the strong link between these two influencing conditions of organizational effectiveness.

\subsection{Customer satisfaction}

Customer satisfaction is an organization's ability to attract and retain customers and to improve customer relationship over time. It is often seen as the satisfaction with an organization's products or services. Furthermore, it is considered to be the key to success and long-term competitiveness. The knowledge of customer satisfaction is the source for the fulfilment of customer expectations, the informed source for gaining their retention and the source for studying organizational effectiveness in the process of service delivery. An organization can decide on the actions required to meet customer needs if it understands perceptions. Furthermore, it can identify its own 
strengths and weaknesses and chart out the strategy of future progress and improvement of the work practices and processes used within the organization.

Customer satisfaction is a hardly universal category because its meaning is based on circumstances and different points of view and is the outcome of individual customer judgement. Researchers of customer satisfaction have developed different concepts and different views of organizational performance outcome. Wilson (2002) argues that customer satisfaction is ambiguous and complex in nature, and it often consists of various components that are measured with different methods under different conditions. Edvardsson (1996) argues that customer satisfaction is an individual category since the customer tacitly understands it in his own unique way. This means that customer satisfaction can be understood as a web of psychological, social and physical variables, which correlate with the notion of a satisfied customer.

Parasuraman, Zeithaml and Berry, (1988) and O'Neill in Palmer (2004) see customer satisfaction as a cognitive construct and as a psychological state. Anderson, Fornell, and Lehman (1994) argue that customer satisfaction is primarily an emotional state and the outcome of the longterm relationship between customers and service providers. Ning-jun Zhang et al (2007) show that the emotional dependency of employees fosters their efforts to satisfy customers. Parasuraman, Zeithaml \& Berry (1988) relate customer satisfaction to qualitative and quantitative elements of the service and see it as a relation between customer satisfaction, service performance, and perceived customer service performance expectations (Oliver, 1997). Zeithaml \& Bitner (2000) propose a simpler definition of customer satisfaction based on the degree of customer needs and expectation satisfaction, which directly impacts the degree of customer dissatisfaction.

Customer satisfaction measures future customer expectations and quality measures what the customer should expect from the service in the future, which is a more abstract category. The outcome of both measures is the relation between expectations and performance (Bolton and Drew 1991; Parasuraman; Zeithaml, and Berry 1988). Empirical analysis has shown that, not only are the actions of employees fundamental for a high-quality delivery of service, but also that their morale influences consumer satisfaction (Schneider and Bowen, 1993).

Based on intensive research through time, two types of customer satisfaction definitions have emerged. The first type defines customer satisfaction as an outcome of a buying experience (Westbrook and Reilly, 1983). The second type of definition defines customer satisfaction as a benchmark between the real purchase and the purchase expectations of the customer (Hunt, 1977). Despite its complexity, customers do not have any problems with the definition of satisfaction even if it is not deliberately explained (Gupta and Zeithaml, 2007). This is the reason it is so important that the management of a service organization primarily sees the customer's point of view of the organisation's strength that results in delivering the service that fulfils the customer's social, personal and physical expectations regarding service quality. Service organizations must consider customer satisfaction as a key leverage point to differentiate themselves from other organisations (Gillespie et al, 2007).

Customer satisfaction is the outcome of his or her needs and expectations which influence the interaction with service providers and other customers. The quality of this interaction impacts customer decisions to repurchase the service, his retention and the intention of the customer to recommend to other potential customers and finally to pass on useful information about the service quality and delivery. Customer satisfaction is related to different ways of interacting with the environment. A positive recommendation is a social interaction, which is positively related to customer retention, reduces transaction costs and increases long-term profitability (Jamieson, 1994, Mackey, 2005). Word of mouth has great communication power because it is a direct transmission of customer satisfaction to other potential customers. Weinberger, Allen and Dillon (1981) and Herr et al (1991), are convinced that word of mouth is more important than information about service generated by marketing activities. The communication power of word of mouth is manifested when the service provider fails to meet the complaints of the customer or his reactions are not congruent with the customer demands. The highest importance of word of mouth is when customer reaction to the service provider is negative (Richins, 1983).

The result of negative perceptions is a dissatisfied customer, who rarely decides to repurchase the service from the same provider (Newman and Werbel, 1973). The worst case is when a customer refuses to buy another service from the same provider (Fitzgibbon and White, 2007). Word of mouth is closely related to the customer intentions to repurchase the service (Gupta and Zeithaml, 2007).

\section{Organizational effectiveness and customer satisfaction}

Customer satisfaction is a complex phenomenon and cannot be collapsed into a single satisfaction index. The customer ultimately judges the strength of his or her relationship with a vendor or service provider on the totality of experiences with the company, of which agent performance is only one required ingredient. Linking organizational culture and customer satisfaction creates some empirical problems. A service can be simulated as a product, but in reality it is not tangible. It does not have a solid form and its physical, psychological and social dimensions are not easily identified and the production of service and deliverance cannot be separated and distinguished. One of the most important facts is that behaviour of the service provider during service delivery and consumption directly influences customer satisfaction. Customer perception during the providing and consumption of the service is focused on the provider and on the service delivery effectiveness, not on the service. Customers are satisfied only 
when they actively participate in the creation, delivery and consummation of the service (Yoo, Donhty and Lee, 2000).

Various social environments impact customer satisfaction. Wangenheim et al (2007) argue that customer satisfaction is social group dependent. Different social groups perceive customer satisfaction with a service differently and the goals of different customers are social group dependent (Mittal and Kamakura, 2001). Castro et al (2007) developed a framework which shows that there are substantial correlations between tourist intentions to revisit a tourist destination and his or her intentions to recommend the tourist destination to his or her relatives and friends. Schneider and Bowen (1993) and Ad de Jong et al. (2005) researched the internal social group environment and found that employees' perceptions of positive group climate positively impact customer perceptions about the service quality.

Service quality and customer satisfaction are related, but different. Bolton and Drew (1991) clearly distinguish between these two groups. Quality is a long-term process and customer satisfaction is a result of the immediate service transaction. Castro et al. (2007) showed that a tourist who decided to revisit a tourist destination recommended it to other tourists. Quality social interaction with employees of the service provider is evidently an important source of customer satisfaction.

Some researchers do not share this view, and argue that service marketing and the quality of service are primary factors that impact a customer's decision to repurchase the service from the same service provider (Nelson, 1994, Getty and Getty, 2003). Customers who are satisfied with the quality of the relations with the employees are more satisfied with the quality of the service (Solnet, 2007). Brown et al. (2001) confirmed that conclusion. Their research shows that quality relations between customers and employees have a positive impact on word of mouth, empower trust between groups, strengthen social interaction and build sincere personal relations. Service organizations tend to employ a cheap work force to maintain their competitive advantage. Seasonal workers and others with low wages are not motivated to build good relations with the customers. The consequences of these actions are mainly reflected in negative word of mouth and in the decision of the customer not to repurchase the service from the same service provider (Sungjin, 2005).

Organizational effectiveness is closely related to the ability of the service provider to satisfy the customer. A service provider who is in a position to offer extra services, such as better quality service, excitement or a large variety of services, will have a greater chance to satisfy a customer (Kano et al., 1984). Lewis and Bridger (2000:126) argue that customers that have an opportunity to save time, to gain personal advantage or to increase their enjoyment, will be more satisfied with the service.

The modern customer is no longer satisfied with the basic attributes of health service. He needs a positive experience and service that can be efficiently applied in his future self-image construction and personal develop- ment. His satisfaction will be even stronger when he is served by employees who genuinely enjoy their work and feel personally involved in providing the service. By improving the procedures and arrangement of health resort physical facilities that offer comfort and ease, by organizing timely and prepared services, and through streamlined contact with customers supported by quality written information, customer experiences are broadened and so is their satisfaction (DiJulius, 1964:53).

Past and recent empirical studies link organizational and customer satisfaction that address service delivery and customer satisfaction, but these relations are more or less theoretical or indirect (Gupta et al., 2005). De Tienne and Holland (2007) relate customer satisfaction to organizational culture by defining it as a consistent, adaptable and qualified process of customer needs satisfaction. Recently, Gillespie et al (2008) showed that organisational culture is a unique phenomenon that must be researched and used as an effectiveness indicator in the environment where a service organisation usually operates. Their recent research in two different organisations on the regional markets of a residential home-building company and automobile dealership show a significant relationship between organizational culture and customer satisfaction.

Bellou (2007) confirmed these findings. She found that long-term customer satisfaction is closely related to the organisational culture which affects employees' eagerness to serve customers. She argues, "as a result, must be organisational agents shape culture in an effective way, by emphasizing aggressiveness, decisiveness, innovativeness and rewards but diminishing outcome orientation". She is convinced that the clear view of the power of the organizational culture by organizational agents serves to emphasize customers' needs and priorities (Bellou, 2007).

Organizations whose cultures are not strongly customer and service oriented, have little chance to succeed. Service organisations must be constantly open to the suggestions, needs and expectations of the customer and open enough to make space for the active participation of the customer in this process. By focusing on the system as a whole, organizations may be better able to satisfy their customers, but in the process also identify areas in need of improvement with respect to their mission, the interaction among employees, and the systems and structures that encourage efficient operations (Denison, 1990).

The current empirical research in two health resorts in Slovenia builds on the organizational culture framework of Denison and colleagues (Denison, 1990; Denison and Mishra, 1995; Fey and Denison, 2003, Gillespie et al., 2008). This framework conceptualizes organizational culture in four dimensions that have been shown to relate to organizational effectiveness: Involvement, Consistency, Adaptability and Mission.

These four dimensions describe the extent to which a company is customer-focused and strategically-oriented (Gillespie et al, 2008). As Denison (1990 : 2) states, the four dimensions measure the underlying values, beliefs, and principles that serve as a foundation for an organiza- 
tion's management system as well as the set of management practices. This organizational model represents a system approach to organizational culture and customer satisfaction and has an impact on organizational effectiveness as described below (Denison, 2000).

Our study is the test of the relationship between organizational culture dimensions and customer satisfaction using service-unit data from two health resorts. The vantage point of our research is based on literature study and empirical findings and starts from the hypothesis that customer satisfaction can be maintained when the members of an organisation share the same values that orient the organisation to customer satisfaction through organisational effectiveness. The new value in our study is a detailed report of customer satisfaction seen by two groups at the same time in the same service organisation. This way we add new perspective to the meaning of customer satisfaction and to the meaning of organisation satisfaction in predicting customer satisfaction.

Hypothesis 1: The better the performance provided by employees, the higher the customer satisfaction.

A performance dimension is closely connected to the capabilities of employees in a service organisation who have knowledge and are motivated to deliver quality services, to their commitment and a sense of ownership. Additionally, it is a competitive advantage of an organisation, which connects the functional capability of employees with organisation strategy, encourages organisational effectiveness and active change processes (Lundby, 2001).

Hypothesis 2: The higher the innovativeness of the services of a health resort, the higher the customer satisfaction.

A service innovation dimension is a special feature of organisational effectiveness that enables an organisation to adapt its goals to customer expectations. Innovativeness is a core and long-term activity of an organisation which is manifested as the creation of new services and as a maintaining of an organisation's competitive advantage (Denison, 1990; Hatch and Cunliffe, 2006). At the same time, innovativeness is an organisation's capacity to innovate. Services structured in a series of processes that are designed and managed to create and apply ideas and knowledge, directed at value creation, are leading to new and different products, service and processes. Innovativeness is an outcome of processes that add new value to service (Bubner, 2001; Edwards et al., 2002; Angel, 2006).

Hypothesis 3: The higher the adaptability of the services of a health resort, the higher the customer satisfaction.

An adaptability dimension is the capability of a service organisation to cope with changes in the service market. An adaptable organization is based on a dynamic network of connections between different internal and external stakeholders who participate in the continuous improvements of the organisation's competitive advantage and customer satisfaction (Brown and Eisenhardt, 1997). The benchmark between successful and less suc- cessful organizations shows that successful organizations foster complete communication, create and recreate organizational environment and climate in order to support continuous low cost improvements.

Hypothesis 4: The stronger the mission of a health resort, the higher the customer satisfaction.

A mission is the capability of a service organization to set clear goals and strategies to sustain a long-term competitive advantage. Effective organizations follow their mission with economic and non-economic goals that make sense and bring meaning to the internal and external stakeholders (Denison and Mishra, 1995; Gillespie et al, 2008). Successful organizations have clear intentions, goals and future vision (Jung et al, 2003; Whetstone, 2005). Their mission is reflected in customer satisfaction. Customers of the organisation with clear goals and mission have positive experiences that empower a positive self-concept and open development perspectives that are realized in the opportunity to be part of the individual service creation delivered by satisfied customers. Wilkins et al (2006) researched the meaning of the self-concept of hotel guests after leaving the hotel. They found that positive experiences with the services of the hotel empowered guests' self-concept, depending on sex and tourist destination.

Hypothesis 5: Perceptions of customer satisfaction in health resorts are different among employees and customers.

Customer satisfaction is complex and research shows that different elements of customer satisfaction in relation to organisational effectiveness are correlated. This is the reason we integrated them into a single factor which was used to test the impact of organizational effectiveness on customer satisfaction in two service organisations in health resorts. Customer satisfaction in our study is measured by the outcome of the benchmark of similar services in similar organisations in health service, with the degree of customer expectation satisfaction, with the quality of customer employee relations and with the ability of service providers to adapt to the service challenges.

\section{Methodology}

\subsection{Methods}

This empirical evidence presents a test of the relationship between the features of organisational effectiveness presented by organizational culture dimensions, and customer satisfaction in two health resorts in Slovenia, one from the inland and the other from the Adriatic coast. During September 2006, 233 respondents, employees and customers from both resorts returned questionnaires. Data were computerized, checked for errors and statistically analysed. To yield four cultural dimensions and to confirm a customer satisfaction indicator we conducted factor analysis - a principal component method with Varimax normalized rotation. 
In the second step of statistical analysis data were regressed to cultural dimensions on a customer indicator to test the relationship between organizational culture dimensions representing organizational effectiveness factors as independent variables and the customer satisfaction indicator as a dependent variable.

\subsection{Sample}

Respondents in our research were selected from among employees from the health resort and among customers or guests that were staying at the resort at the time of conducting the study. Employees and guests assessed the organizational effectiveness and customer satisfaction in the health resort at the same time. Respondents from both groups, employees and guests, were randomly selected with all having the same chance to be selected, and mirror the structure at the time the questionnaire was administered. Questionnaires were distributed personally by the researcher. About $10 \%$ of respondents refused to participate in the study. Respondents from the guest sample visited the health resort on account of chronic health problems. In the Adriatic coast health resort, there were many respondents that visited it on account of health problems and for pleasure.

In the first resort from the inland (DT), 57 guests, 26 men and 31 women, with 55.37 years of average work experience and 57 frontline, administrative and health and medical staff, 20 men and 37 women, with 17.35 years of average work experience, filled out and returned the questionnaire containing items about organisational effectiveness and customer satisfaction. In the second resort from an Adriatic coast (K), 61 guests, 18 men and 43 women, with 31.60 years of work experience, filled out and returned the questionnaire and 58 frontline, admin- istrative and health and medicine staff, 20 men and 38 women, with 17.35 years of working experience, filled out and returned the questionnaire.

\subsection{Instrument}

We chose a quantitative study with survey instruments to benchmark differences and similarities between the samples in the study and between the health resorts in the study. To test the relationship between organizational culture dimensions and customer satisfaction, a survey instrument with a five point Likert-type continuous scale was developed. The scale of the instrument ranged from (1) absolutely disagree with the statement to (5) absolutely agree with the statement. As a base for the current study in two health resorts in Slovenia is the organizational culture framework of Denison (1990). Four dimensions of an organizational culture were developed consisting of: Performance dimension: quality of service, customer expectation fulfillment, readiness of the employees to understand and serve problem solutions and to process information to the customers, trust in employees, longterm oriented system approach toward customers.

Innovation dimension: generating new products and services, integrating packaged services in various combinations, performing service animations, inclusion of the customer in service creation:

- A performance dimension: quality of service, customer expectation fulfillment, readiness of the employees to understand and assist in solving problems and to process information to the customers, trust in employees, long-term oriented system approach toward customers.

- An innovation dimension: generating new products and services, integrating packaged services in various

Table 1: Sample features of respondents in the study

\begin{tabular}{|c|c|c|c|c|c|}
\hline Sample & Sex & & $\begin{array}{l}\text { Age } \\
\text { (average for both } \\
\text { groups) }\end{array}$ & $\begin{array}{l}\text { Working } \\
\text { experience } \\
\text { (average) }\end{array}$ & $\begin{array}{l}\text { Days of } \\
\text { staying }\end{array}$ \\
\hline \multirow{2}{*}{$\begin{array}{l}\text { Inland resort (DT) } \\
\text { guests }\end{array}$} & Male & 26 & \multirow[t]{2}{*}{55.73} & \multirow[t]{2}{*}{25.80} & \multirow[t]{2}{*}{1.84} \\
\hline & Female & 31 & & & \\
\hline \multirow{2}{*}{$\begin{array}{l}\text { Inland resort (DT) } \\
\text { employees }\end{array}$} & Male & 14 & \multirow[t]{2}{*}{38.26} & \multirow[t]{2}{*}{16.89} & \\
\hline & Female & 43 & & & \\
\hline \multirow{2}{*}{$\begin{array}{l}\text { Adriatic coast resort } \\
(\mathrm{K}) \text { guests }\end{array}$} & Male & 18 & \multirow[t]{2}{*}{62.67} & \multirow[t]{2}{*}{31.60} & \multirow[t]{2}{*}{2.10} \\
\hline & Female & 43 & & & \\
\hline \multirow{2}{*}{$\begin{array}{l}\text { Adriatic coast resort } \\
(\mathrm{K}) \text { employees }\end{array}$} & Male & 20 & \multirow[t]{2}{*}{36.98} & \multirow[t]{2}{*}{17.35} & \\
\hline & Female & 38 & & & \\
\hline
\end{tabular}


combinations, performing service animations, inclusion of the customer in service creation.

- An adaptability dimension: comfort of the buildings, deliverance service capability, continuous service improvement, professional behaviour of the staff, introduction.

- A mission dimension: management and staff responsiveness, business opportunity exploration, clearness of goals and organization strategy, development of employees.

- Customer satisfaction: quality of service, expectation fulfillment, service repurchase intent, likeness to the organization staff, timetable suitability, comfort of buildings, quality and frequency of information about services, openness to change.

\section{Findings and discussion}

Descriptive statistics for the determining factors of organizational effectiveness and customer satisfaction are presented in Table 2 and in Table 3. It can be seen that the mean scores for effectiveness factors vary between 3.46 and 4.37, respectively, innovativeness being the least

Table 2: Organizational effectiveness and factors

\begin{tabular}{|c|c|c|c|c|}
\hline Factor analysis & Eigenvalues & $\begin{array}{l}\text { Explained } \\
\text { variance }\end{array}$ & $\begin{array}{l}\text { Reliability } \\
\text { (Cronbach } \\
\text { alfa) }\end{array}$ & Mean \\
\hline \multicolumn{5}{|l|}{ Involvement and factor } \\
\hline \multirow{2}{*}{$\begin{array}{l}\text { Our customer always receives quality service. } \\
\text { I am sure that employees will fulfil customer } \\
\text { expectations. }\end{array}$} & 0.72 & \multirow{12}{*}{$34 \%$} & \multirow{12}{*}{0.94} & 4.42 \\
\hline & 0.73 & & & 4.35 \\
\hline Employees are always willing to help. & 0.85 & & & 4.51 \\
\hline \multirow{2}{*}{$\begin{array}{l}\text { Employees sincerely want to please customer. } \\
\text { Employees always help to solve problems of the } \\
\text { customers. }\end{array}$} & 0.82 & & & 4.51 \\
\hline & 0.77 & & & 4.27 \\
\hline $\begin{array}{l}\text { The behaviour of employees confirms trust in } \\
\text { them. }\end{array}$ & 0.83 & & & 4.32 \\
\hline Employees provoke good feelings in customers. & 0.87 & & & 4.48 \\
\hline Employees are always nice. & 0.80 & & & 4.44 \\
\hline \multirow{2}{*}{$\begin{array}{l}\text { Customer gets information, whenever he wants. } \\
\text { Employees definitely want to understand } \\
\text { customers. }\end{array}$} & 0.80 & & & 4.36 \\
\hline & 0.70 & & & 4.25 \\
\hline $\begin{array}{l}\text { Employees work systematically, gradually and } \\
\text { long-term oriented. }\end{array}$ & 0.55 & & & 4.27 \\
\hline $\begin{array}{l}\text { Customers know to whom to turn to get } \\
\text { information about service. }\end{array}$ & 0.62 & & & 4.26 \\
\hline \multicolumn{5}{|l|}{ Innovativeness and factor } \\
\hline The organization introduces new services. & 0.92 & & & 3.47 \\
\hline The organization combines different services. & 0.92 & & & 3.43 \\
\hline The organization introduces priced packages. & 0.92 & $17 \%$ & 0.95 & 3.55 \\
\hline The organization offers animation services. & 0.89 & & & 3.40 \\
\hline The organization services are unique. & 0.89 & & & 3.47 \\
\hline \multicolumn{5}{|l|}{ Adaptability and factor } \\
\hline \multirow{2}{*}{$\begin{array}{l}\text { Facilities of the organization are comfortable. } \\
\text { Organization demonstrates deliverance service } \\
\text { capability. }\end{array}$} & 0.75 & \multirow{5}{*}{$9 \%$} & \multirow{5}{*}{0.89} & 4.00 \\
\hline & 0.86 & & & 4.17 \\
\hline \multirow{2}{*}{$\begin{array}{l}\text { The organization continuously improves services. } \\
\text { The staff in organization conducting } \\
\text { professionally. }\end{array}$} & 0.83 & & & 4.21 \\
\hline & 0.80 & & & 4.31 \\
\hline $\begin{array}{l}\text { The organization introduces individually oriented } \\
\text { services. }\end{array}$ & 0.64 & & & 4.08 \\
\hline \multicolumn{5}{|l|}{ Mission and factor } \\
\hline $\begin{array}{l}\text { The management and staff in organization } \\
\text { successfully respond to the demands of the } \\
\text { circumstances. }\end{array}$ & 0.77 & & & 4.15 \\
\hline $\begin{array}{l}\text { The organization successfully takes advantages of } \\
\text { business opportunities. }\end{array}$ & 0.75 & $8 \%$ & 0.77 & 3.89 \\
\hline The organization has clear goals and strategy. & 0.79 & & & 4.39 \\
\hline $\begin{array}{l}\text { The organization takes care of the employees' } \\
\text { personal development. }\end{array}$ & 0.75 & & & 4.08 \\
\hline
\end{tabular}


prominent and performance being the most prominent characteristics of organizational effectiveness in the two health resorts in Slovenia. We can conclude from our findings that the organizations studied underestimate the importance of innovativeness of services to retain a competitive advantage. Innovation can make an obvious difference and keep the organization competitive.

We used factor analysis of principal components with Varimax standardized rotation to reduce the number of variables in the research. Factor analysis was conducted separately for the variables from the organizational effectiveness group and for the variables from the customer satisfaction group. To control reliability, Cronbach's alpha was used to separately assess the reliability of the scales generated by factor analysis. We found that the scales generated after factor analysis are reliable and can be used to assess organizational effectiveness and customer satisfaction (Table 2).

The first group of variables yielded five factors that explain $68 \%$ (Table 2) of variance and was named "Organizational effectiveness". The first factor "Performance" is the strongest and explains $34 \%$ of the variance, followed by the factor "Innovativeness" that explains $17 \%$ of the variability. The third factor in the analysis was named "Adaptability" and explained $9 \%$ of the variance. The last factor named "Mission" explained $8 \%$ of the variance. The analysis shows that service performance in perceived as the most important factor of service delivery based on the behaviour pattern of employees in the process of service delivery. Furthermore, results show that the organization mission is not a well known and well accepted organizational effectiveness factor in the process of service delivery. Employees and customers did not give it much importance in ranking organizational effectiveness. The second group of variables yielded only one factor that explains $44 \%$ of the variance and was named "Customer satisfaction". The results are not a surprise. They only confirm the fact that customer satisfaction is a complex phenomenon that must be studied as a combination of several types of customer satisfaction.

The first objective of this study was to examine the extent to which organisational effectiveness can predict customer service orientation, in an effort to provide insight into customer satisfaction (Table 3). To test the composite level of impact that any of the independent variables has upon customer contribution, General Linear Regression was used and the impact captured by $\mathrm{F}$ and $\mathrm{p}$ value. Results show that organisational effectiveness factors have an impact on customer satisfaction (R2, adjusted $=0.64, \mathrm{p}<0.00000 * * *)$. In the regression model, the organisational effectiveness factor has the strongest correlation with customer satisfaction $(\mathrm{F}=149 ; \mathrm{p}<0$. $00000 * * *)$. Since factor innovativeness has no significant correlation with customer satisfaction $(F=2.65 ; \mathrm{p}<0.10)$, we must reject the hypothesis that the higher the adaptability of the services of a health resort, the higher the customer satisfaction. According to Table 5, three organisational effectiveness variables and one control variable (groups) are important customer service predictors.

Apparently, performance, adaptability, mission and control variable groups significantly impact the extent to which employees and customers put customers' interests first. According to the results of the study, we can accept the hypotheses that performance of employees, the adaptability to customer needs and a clear organization mission predict customer satisfaction. Such a finding implies that employees and customers recognize that being competitive as a service organisation tends to be perfectly included in service delivery, to have a clear vision of what service largely means to customers and to be flexible in all circumstances regarding service delivery. In addition,

Table 3: Customer satisfaction and factor

\begin{tabular}{|c|c|c|c|c|}
\hline Factor analysis & Eigenvalues & $\begin{array}{l}\text { Explained } \\
\text { variance }\end{array}$ & $\begin{array}{l}\text { Reliability } \\
\text { (Cronbach } \\
\text { alfa) }\end{array}$ & Mean \\
\hline \multicolumn{5}{|l|}{ Customer satisfaction and factor } \\
\hline \multirow{2}{*}{$\begin{array}{l}\text { Higher quality service that in other health resorts. } \\
\text { Quality of services satisfies customer } \\
\text { expectations. }\end{array}$} & 0.68 & & & 3.89 \\
\hline & 0.82 & & & 4.22 \\
\hline $\begin{array}{l}\text { Customer would repurchase the service in this } \\
\text { health resort. }\end{array}$ & 0.79 & & & 4.30 \\
\hline $\begin{array}{l}\text { Customer looks forward to meet the resort staff } \\
\text { again in the future. }\end{array}$ & 0.67 & & & 4.39 \\
\hline $\begin{array}{l}\text { Customer is comfortable with the time table in } \\
\text { resort. }\end{array}$ & 0.53 & $44 \%$ & 0,84 & 4.08 \\
\hline $\begin{array}{l}\text { Facilities are comfortable, streamlined and timely } \\
\text { prepared. }\end{array}$ & 0.63 & & & 3.98 \\
\hline $\begin{array}{l}\text { Customer receives high quality information about } \\
\text { services. }\end{array}$ & 0.66 & & & 4.23 \\
\hline $\begin{array}{l}\text { Customer is frequently informed about services in } \\
\text { the resort. }\end{array}$ & 0.57 & & & 4.30 \\
\hline Health resort is open to changes. & 0.58 & & & 3.96 \\
\hline
\end{tabular}


Table 4: Results of regression analysis

\begin{tabular}{|c|c|c|c|c|c|c|c|}
\hline Independent variables & Mean & $\begin{array}{l}\text { Standard } \\
\text { deviance }\end{array}$ & $\overline{\mathbf{R}^{2}}$ & $\overline{\mathbf{R}^{2,}}$ & $\Delta \mathbf{R}^{2}$ & $\mathbf{F}$ & $\mathbf{p}$ \\
\hline intercept & & & & & & 6,21 & $0.013498^{*}$ \\
\hline $\begin{array}{l}\text { Performance } \\
\text { dimension }\end{array}$ & 4.37 & 0.099178 & & & & 149 & $0.000000^{* * *}$ \\
\hline $\begin{array}{l}\text { Innovativeness } \\
\text { dimension }\end{array}$ & 3.46 & 0.056391 & & & & 2.65 & 0.105158 \\
\hline Adaptability dimension & 4.15 & 0.119290 & & & & 10.65 & $0.001287^{*}$ \\
\hline Mission dimension & 4.12 & 0.206620 & & & & 18.38 & $0.000028^{*}$ \\
\hline Respondents & & & & & & 4.50 & $0.004390 *$ \\
\hline Customer satisfaction & 4.15 & 0.177 & 0.81 & 0.66 & 0.64 & 55.95 & $0.00000 * * *$ \\
\hline error & & & 22.94 & 208 & 0.11 & & \\
\hline
\end{tabular}

Notes: $p<0.05^{*} ; p<0.01^{* *} ; p<0.001^{* * *}$

being competitive means to have in mind that different groups have different perceptions of customer satisfaction.

We tested findings of regression analysis on the statistical significant difference between employees and customers using the Scheffe Multivariate Test (Table 5), which can be used when means are not equal, non-homogeneous or non-normally distributed. Results show that the perceptions of the customers in resort $(\mathrm{K})$ significantly differentiate from the perceptions of the employees in (K) and from the customers and employees in (DT).

Repeating multiple regression separately for the organization revealed both similarities and differences (Table 6). Organization (DT) is an old health resort. Both employees and customers believe that for organization (DT) the strongest organizational effectiveness factor is service performance - the capacity of its employees to perform and to deliver service that fulfils customer expectations, combined with the second factor - adaptability, understood as a capability for teamwork and deliverance of individual service for each customer. Health resort (K) has a different organizational effectiveness structure. Employees and customer perceptions in $(\mathrm{K})$ resort differ significantly. Customers are more satisfied with employees' performance in service delivery and with the mission of the health resort.

Service performance is the most important positive similarity in a complete sample and in groups by health resort. An effective service organization is an organization with employees that have skills and knowledge and are committed to service delivery to satisfy customers. On the other hand, the most important negative similarity is the absence of new services. It seems that both resorts are effective in selling well proven services to the customers, and they are satisfied. Performance based on stability and predictability prevails over innovativeness and excitement. Customers in both resorts are mostly aged populations ( $\mathrm{K}=$ average 63 years; DT = average 56 years) who value predictability and effective service delivery and are

Table 5: Post Hoc Tests

\begin{tabular}{llllll}
\hline \multicolumn{5}{l}{ Scheffe test; variable Probabilities for Post Hoc Tests Error: Between } & MSE $=, 11026, \mathrm{df}=208,00$ \\
\hline & respondents & $\{\mathbf{1}\}$ & $\{\mathbf{2}\}$ & $\{\mathbf{3}\}$ & $\{\mathbf{4}\}$ \\
\hline $\mathbf{1}$ & DT_customers & & 0.249885 & 0.999828 & $\mathbf{0 . 0 0 0 0 0 1}$ \\
$\mathbf{2}$ & DT_employees & 0.249885 & & 0.291156 & $\mathbf{0 . 0 0 2 9 2 4}$ \\
$\mathbf{3}$ & S_employees & 0.999828 & 0.291156 & & $\mathbf{0 . 0 0 0 0 0 2}$ \\
$\mathbf{4}$ & S_employees & $\mathbf{0 . 0 0 0 0 0 1}$ & $\mathbf{0 . 0 0 2 9 2 4}$ & $\mathbf{0 . 0 0 0 0 0 2}$ & \\
\hline
\end{tabular}

Table 6: Sample regression results

\begin{tabular}{llcl}
\hline Independent variables & All organisations & Organisation (DT) & Organisation (K) \\
\hline An performance & $0.65^{* * *}$ & $0,569036^{* * *}$ & $0,559129^{* * *}$ \\
An innovativeness & -0.11 & $-0,027788$ & $-0,113289$ \\
An adaptability & $0.22^{*}$ & $0,447030^{* * *}$ & 0,043624 \\
A mission & $0.28^{* *}$ & 0,153282 & $0,421328^{* *}$ \\
Groups & $0.14^{*}$ & $-0,052551$ & $-0,413341^{* *}$ \\
Adjusted R & 0.64 & 0.70 & 0.61 \\
F - ratio & 56 & 53 & 32 \\
\hline
\end{tabular}


a population who has very defined needs related to health improvement.

However, there are some differences as well so we can accept our hypothesis that perceptions of employees and customers are different. Resort $(\mathrm{K})$ is more of a goal and new opportunity oriented resort and resort (DT) is more conservative and oriented to producing quality health treatment services (Table 6). Evaluating competition from a customer's perspective encourages a broader view of competition because customers are not bound by the typical single-industry definition of competition. Market-oriented firms attempting to satisfy customers' needs and wants should have an interest in understanding how their customers select products in the face of wide-ranging competition. Developing an organizational effectiveness which fosters satisfaction can provide a competitive advantage to the service organization. It is thus critical for organizational agents to have a clear view of the existing effectiveness but also to shape it in such a way that emphasizes customer needs and priorities (Bellou, 2007).

As we noted before, the findings of our research show that service performance is a core competence of the service organization in our sample. Employees that are qualified, trusted and flexible are a service organization asset. Quality relations between employees and customers are the best way to develop a customer oriented organization. Our research findings confirm that organizational effectiveness is important in building a service oriented organization. However, organizational effectiveness is a result of many cultural, physical and psychological factors. It is multifaceted and reflects organizational culture practices, customer needs, wants and expectations. In order to achieve successful implementation of initiatives, the human resource management practices in a health resort must be designed accordingly, by recruiting and selecting applicants that fit the organization. Newcomers should be effectively involved in organization operations, procedures, and standards (Bellou, 2007).

Service innovation in a health resort is another feature which needs more attention in future research. Service is not tangible and cannot be innovated in the same way as a physical product. Service innovation in the health and beauty sector takes time and new services are accepted when new life styles or new health treatment services are developed. Furthermore, this can be realized when employees fully understand the mission of their organization and follow it with a firm belief in better customer service. The findings of our research show that service innovativeness is not a significant independent variable in our sample and rather limited (3.46 on a five-point Likert scale), implying that there are still a lot of innovative opportunities for customer needs satisfaction with added services. If health resort managers are to avoid mistakes that arise from a limited view of innovation opportunities in the present situation, then new, innovative and continuous improvement competitive health service forms must be identified and considered when developing future marketing strategies.

\subsection{Limitations of the study}

This study has some limitations that need to be taken into consideration when interpreting the results. First of all, employees and customers assessed both organizational effectiveness and customer service orientation. As a result, one cannot be certain that there was no common method variance. Secondly, only two health resorts in Slovenia were included in our sample. To assess the complete impact of the organizational effectiveness factors in health resorts, future research should include all health resorts in Slovenia.

\subsection{Implications for future research}

Despite these limitations, it is strongly believed that the findings of this study provide a platform for understanding the complexity of customer satisfaction in relation to organizational effectiveness. Our findings reveal that different groups positively have priority of different organizational factors. Future research should include groups of employees and customers that will assess the same services to detect the customer oriented organizational culture of health resorts.

\section{Conclusions}

Ensuring survival of the service organization in the long run requires adaptations which are oriented towards achieving maximum customer satisfaction. This study intended to unveil the effect organizational factors have on customer service orientation from the customer and employee point of view within a health resort service setting. The findings suggest that when trying to predict the impact which organizational effectiveness factors have in satisfying customers' needs, performance, adaptability and mission factors can be of the highest importance. Developing a culture which fosters customer satisfaction can provide a competitive advantage to the organization. It is thus critical for organizational agents not only to have a clear view of the existing culture but also to shape it in such a way that emphasizes customer needs and priorities.

\section{References}

Ad de Jong, Ko de Ruyter \& Lemmink, J. (2005). Service Climate in Self-Managing Teams: Mapping the Linkage of Team Member Perceptions and Service Performance Outcomes in a Business-to-Business Setting. Journal of Management Studies, 42(8): 1593-1620.

Ambrož, M. (2004). Total quality system as a product of the empowered corporate culture. The TQM magazine, 16(2): 93-104.

Anderson, E. W., Fornell, C. \& Rust, R. (1997), Customer Satisfaction, Productivity, and Profitability: Differences between Goods and Services, Marketing Science, 16(2): 129-145. 
Anderson, E. W., Fornell, C. \& Lehman, D. R. (1994). Customer Satisfaction, Market Share, and Profitability: Findings from Sweden, Journal of Marketing, 598 (July): 53-66.

Angel, R. (2006). Putting an innovation culture into practice. Ivey Business Journal, Issue January/February, Richard Ivey School of Business.

Bellou, V. (2007). Achieving long-term customer satisfaction through organizational culture: Evidence from the health care sector. Managing Service Quality, 17(5): 510 - 522 Emerald Group Publishing Limited.

Bitner, M. J. (1990). Evaluating Service Encounters Effects of Physical Surroundings and Employee Responses. Journal of Marketing, 54(2): 69-82.

Blake E. Ashforth, B. E. \& Mael, F. (1989). Social Identity Theory and the Organization. The Academy of Management Review, 14(1): 20-39.

Bolton, R. N. \& Drew, J. H. (1991), A Multistage Model of Customers Assessments of Service Quality and Value. Journal of Consumer Research, 17(4): 375-84.

Bowen, D. E., Schneider, B. \& Kim, S.S. (2000). Shaping service cultures through strategic human resource management, in Swartz, T. and Iacobucci, D. (Eds), Handbook of Services Marketing and Management, Sage Publications, Thousand Oaks, CA: 439-54.

Brown, S., Gremler, D. \& Gwinner, K. (2001). Generating positive word-of-mouth communication through customer-employee relationships International Journal of Service Industry Management. 12(1): 469-482.

Brown, S. L., Kathleen M. \& Eisenhardt , K. M.(1997). The Art of Continuous Change: Linking Complexity Theory and Time-Paced Evolution in Relentlessly Shifting Organizations Administrative Science Quarterly, 42(1), (Mar., 1997): 1-34.

Bubner,D. (2001). In 5th International and 8th National Research Conference on Quality and Innovation Management (Ed. Terziovski, D. M.) The Euro Australasian Cooperation Centre (EACC), Victoria, Melbourne.

Castro, C. B., Armario, E. M. \& Ruiz, D. M. (2007). The influence of market heterogeneity on the relationship between a destination's image and tourists' future behaviour. Tourism Management, 28(1): 175-187.

Conduit, J. \& Mavondo, F.T (2001). Does internal customer orientation matter? Journal of Business Research, 51(1): 11-24.

Conrad, C. A., Brown, G.\& Harmon, H. A. (1997). Customer satisfaction and corporate culture: A profile deviation analysis of a relationship marketing outcome. Psychology \& Marketing, 14: 663-674.

Cronbach, L. J. (1951). Coefficient alpha and the internal structure of tests. Psychometrika, 16(3): 297-334.

Denison, D. R., \& Mishra, A. K., (1995). Toward a theory of organizational culture and

effectiveness, Organization Science, 6: 204-223.

Denison, D. (1990). Corporate culture and organizational effectiveness. New York: Wiley.

Detert, J. R. et al. (2000). A framework for linking culture and improvement initiatives in organizations. Academy of Management Review, 25(4), 850-863.

DeTienne, K. B. \& Holland, A.S., (2007). An empirical investigation of the components of quality service operations: a B2B analysis. Available from: http://www.swdsi.org/ swdsi07/2007 proceedings/papers/706“.pdf

DiJulius, J. R. (1964). Secret Service: Hidden Systems that Deliver Unforgettable Customer Service (New York: American Management Association, (2003), 4.
Edwards, R. W., Kumar, P. \& Ranjan, R. (2002). Understanding Organisation Culture and Innovation: A Case Study Approach.Available at:http://www.aueb.gr/deos/EIBA2002. files/PAPERS/C204.pdf

Edvardsson, B., Brown, S. W., Johnston, R. \& Scheuing, E. E. (eds.) (1996) Advancing Service Quality: A global perspective, QUIS 5, International Service Quality Association Inc, NY.

Fey, C. F. \& Denison, D. (2003). Organizational culture and effectiveness: Can American theory be applied in Russia? Organization Science, 14(6): 686-706.

Fitzgibbon, C. E., \& White, L. (2007) An Investigation into Consumer Tolerance of Negative Service Experiences and Its Relationship to Length of Patronage and Attitudinal Loyalty Macquarie University available from: www. serviceuntitled.com/negative-experience-with-adorama/2007/06/04/

Gilbert, G. R. \& Parhizgari, A.M. (2000), Organisational effectiveness indicators to support service quality, Managing Service Quality, 10(1): 46-51.

Gupta, A., McDaniel, J.C. \& Herath, S.K. (2005). Quality management in service firms:

sustaining structures of total quality service. Managing Service Quality, 15(4): 389-402.

Getty, J. M., \& Getty, R.L. (2003). Lodging Quality Index (LQI): Assessing hotel guests' perceptions of quality delivery. International Journal of Contemporary Hospitality Management, 15(2), 94-104.

Gilbert G, R. \& Parhizgari A. M.(2000). Organizational effectiveness indicators to support service quality. Managing Service Quality, 10(1):46-51.

Gillespie, M. A., Denison, D. R., Haaland, S., Smerek, R. \& Neale, W. S. (2008). Linking organizational culture and customer satisfaction: Results from two companies in different industries. European Journal of Work and Organizational Psychology, 17(1): 112-132.

Gupta, S. \& Zeithaml, V.A. (2007). Customer metrics and their impact on financial performance, Marketing Science (forthcoming).

Hasmi, M. \& Asaari, A. H. (2007). Strategic decision making practices and organization performance: A conceptual perspective of Malaysian organizations. Oxford Business and Economics Conference, June 24-26, UK, Oxford University.

Harrison, J. R., \& Glenn, R. C. (1991). Keeping the Faith: A Model of Cultural Transmission in Formal Organizations, Administrative Science Quarterly, 36(December): 552-582.

Hatch, M. J. \& Cunliffe, A. L. (2006). Organization Theory: second edition: modern, symbolic, and postmodern perspectives. Oxford University Press.

Herr, P. M., Kardes, F. R. \& Kim, J. (1991). Effects of Wordof-Mouth and Product-Attribute Information on Persuasion: An Accessibility-Diagnosticity Perspective. The Journal of Consumer Research, 17(4): 454-462.

Heiser, R. S., McQuitty, S. \& Stratemeyer, A.W.(2005). Revisiting Competition: Broadening the Competitive Environment. The Academy of Marketing Science Review, 12, Available: http://www.amsreview.org/articles/heiser 12-2005.pdf.

Hofstede, G. (1980). Culture's Consequences: International Differences in Work Related Values, Beverly Hills, CA, Sage Publications.

Hofstede, G. (1991). Cultures and organizations, London: McGraw-Hill.

Hunt, H. K. (1977). CS/DBOverview and Future Research Direction, in Conceptualizaton and Measurement of 
Consumer Satisfaction and Dissatisfaction, H. Keith Hunt, ed. Cambridge, MA: Marketing Science Institute.

Igo, T. \& Skitmore, M. (2006) Diagnosing the organisational culture of an Australian engineering consultancy using the competing values framework. Construction Innovation, 6(2):121-139.

Jamieson, D. (1994). Customer Retention: Focus or Failure. The TQM Magazine, 6(5): 11 - 13.

Jung, D., Chow, C. \&Wu, A. (2003). The role of transformational leadership in enhancing organizational innovation: Hypotheses and some preliminary findings. The Leadership Quarterly, 14(4-5): 525-544.

Kano, N., Seraku, N., Takahashi, F. \& Tsuji, S. (1984). Attractive quality and must-be quality. Hinshitsu. Quality, The Journal of the Japanese Society for Quality Control, 14(2): 39-48.

Kennedy, P.W. (1994). Word-of-mouth communication and price as a signal of quality. Economic record, 70.

Kotter, J. \& Hesket, J. (1992). Corporate Culture and Performance. New York: The Free Press.

Kwantes, T. C. \& Boglarsky, C. A. (2007). Perceptions of organizational culture, leadership effectiveness and personal effectiveness across six countries, Journal of International Management, 13(2): 204-230.

Lewis, D. \& Bridger, D. (2000). The Soul of the New Consumer: Authenticity: What we buy and Why in the New Economy. Nicholas Brealey Publishing.

Lewis, D. (2002). Five years on - the organizational culture saga revisited. Leadership \& Organization Development Journal, 23(5): 280-287.

Lundby, K., Fenlason, K., \& Magnan, S. (2001). Linking employee and customer data

to business performance- Difficult but not impossible: Some lessons from the

field. Consulting Psychology Journal, 5(1): 23-34.

Mackey, J. (2005). Franchisers reap multiple benefits from increasing customer loyalty.

Franchising World, 37(5): 49.

Mittal, V. \& Kamakura,W.A. (2001). Satisfaction, Repurchase Intent, and Repurchase Behavior: Investigating the Moderating Effect of Customer Characteristics. Journal of Marketing Research, 38(1): 131-142.

Nelson, P. (1974), Advertising as information. Journal of Political Economy. 81: 729-54.

Newman, J. W. \& Werbel. R. A. (1973). Multivariate Analysis of Brand Loyalty for Major Household Appliances. Journal of Marketing Research 10: 404-09.

Newman, J. W. \& Richard A. W. (1973). Multivariate Analysis of Brand Loyalty for Major Household Appliances. Journal of Marketing Research, 10 (November): 404-9.

Ning-jun, Zhang, Yong-zhong, Jiang \&Li Qin (2007). Connecting Service Employee apos;s Organizational Commitment with Customer Perception: A Conceptual Model. Service Systems and Service Management, International Conference, 9-11 June 2007:1 - 11.

O'Donovan, G. (2006). The Corporate Culture Handbook: How to Plan, Implement and Measure a Successful Culture Change Programme, The Liffey Press.

Oliver R. L. (1993). Cognitive, Affective, and Attribute Bases of the Satisfaction Response. Journal of Consumer Research, 20(4):1-13.

O'Neill, M. \& Palmer, A. (2004). Cognitive dissonance and the stability of service quality perceptions. Journal of Services Marketing , 18(6): 433 - 449.

O'Neill, J. W., Beauvais, L.L \& Scholl, R.W. (2001). The use of organizational culture and structure to guide strategic behaviour: an information processing perspective. The journal of behavioural and Applied Management, 2(2): 131-150.

Ouchi, W. G. (1981). Theory Z: How American business can meet the Japanese challenge. New York: Avon Books.

ParasuramanA.,ZeithamlV.A.\& Berry L.L.(1988).SERVQUAL A Multiple-Item Scale for Measuring Consumer Perceptions of Service Quality. Journal of Retailing, 64(1):12-40.

Parasuraman A., Zeithaml V. A. \& Berry L. L. (1985). A Conceptual Model of Service Quality and Its Implications for Future Research, Journal of Marketing, 49(4): 41-50.

Parasuraman A.,Zeithaml V.A. \& Berry L.L.(1991). Refinement and Reassessment of the SERVQUAL Scale, Journal of Retailing, 1991, 67(4): 420-450.

Richins, M. L. (1983). Negative Word-of-Mouth by Dissatisfied Consumers: A Pilot Study. Journal of Marketing, 47 (Winter), $68 \mathrm{~B} 78$.

Schein, E. H. (1996) The Three Cultures of Management: Implications for Organizational Learning. Sloan Management Review, 38: 9-20.

Subramony, M., Conduit, J. \& Mavondo, F. T. (2000). Market Orientation and Internal Customer Orientation:Implications For Employee Perceptions. ANZMAC 2000 Visionary Marketing for the 21st Century: Facing the Challenge.

Schneider, B., Parkington, J. J. \& Buxton, M. V. (1980). Employee and Customer Perceptions of Service in Banks. Administrative Science Quarterly, 25(2): 252-267.

Schneider, B. \& Bowen, D.E. (1995). Winning the Service Game, Harvard Business School Press, Boston, MA.

Schneider, B. \& Bowen, D. (1993). The service organisation: Human resource management is crucial. Organisational Dynamics, 21(4)39-52.

Shahani-Denning, C. (2000). Employee and customer perceptions of service quality: A look at India. Current Psychology, 19 (4): 292-300.

Solnet, G. (2007). Social Identity theory: A role in hotel industry research. In: Christou, E. and Sigala, M. 2007 I-Chrie Conference, Dallas, Texas USA, 25-29 July 2007.

Stein, M. M. \& Bowen, M. (2003). Organizational change. Building a customer satisfaction system: Effective listening when the customer speaks. Wiley Periodicals, Inc, Journal of Organizational Excellence, 22(3): 23 - 34.

Subramony, M., Beehr, T. A. \& Johnson, C. M. (2004). Employee and Customer Perceptions of service Quality in an Indian Firm. Applied Psychology, 53(2): 311-327.

Sungjin, Y (2005). Service Quality at Hospitals, In Asia Pacific Advances in Consumer Research Volume 6, eds. Yong-Uon Ha and Youjae Yi, Duluth, M. N.: Association for Consumer Research: 188-193.

Trice, H. M. and Beyer, J.M. (1993). The cultures of work organizations. New Jersey:

Prentice-Hall, Inc.

Yoo, B., Donthu, N. \& Sungho, L., (2000). An Examination of Selected Marketing Mix Elements and Brand Equity. Journal of the Academy of Marketing Science, 28: 195-211.

Schneider, B., White, S.S. \& Paul, M.C. (1998). Linking service climate and customer

perceptions of service quality: Test of a causal model. Journal of Applied Psychology, 83:

150-163.

Zeithaml, V. A. \& M. J. Bitner, M. J. (2000). Services Marketing. Integrating Customer Focus Across the Firm. 2nd Ed. Boston etc.: Irwin McGraw-Hill.

Whetstone, J. T. (2005). A framework for organizational virtue: the interrelationship of mission, culture and leadership Business Ethics. An European Review, 14(4): 367-378. 
Wangenheim, F. V., Evanschitzky, H. \& Wunderlich, M. (2007). Does the employee-customer satisfaction link hold for all employee groups? Journal of Business Research. 60(7): 690-697.

Weinberger, Marc G., Chris T. Allen \& William R. Dillon (1981). Negative Information: Perspectives and Research Directions. Advances in Consumer Research, 8, 398-404.

Westbrook, R.A.\& Reilly, M. D. (1983). Value-Percept Disparity: An Alternative to the Disconfirmation of Expectations Theory of Consumer Satisfaction, in Advances in Consumer Research, Richard P. Bagozzi and Alice M. Tybout, eds. Ann Arbor, MI: Association for Consumer Research, 256-61.

Westbrook, J. D. (1993). Organizational culture and its relationship to TQM. Industrial management January/February: $1-3$.

Wilkins, H. Merrilees, B. \& Herington, C. (2006). How SelfImage Congruence Impacts Customer Satisfaction in Hotels. Tourism Analysis, 11(5):311-318.

Wilson, A. (2002). Attitudes towards customer satisfaction measurement in the retail sector. International Journal of Market Research. 44(2):213-22.
Milan Ambrož is an assistant professor in sociology of tourism. He lectures as a visiting lecturer in MA in Criminal Justice and Security Studies on the Faculty of Criminal Justice and Security Studies, University of Maribor on security management and security culture. He also consults to the management of companies and organizations on business process efficiency, human resource development and marketing.

Martina Praprotnik holds the college diploma on organizational culture in the hotel company from University of Primorska, Turistica - Faculty for Tourism Studies, Portorož. She consults in the field of healthy food and health life-style development. She is also a personal trainer in aerobics.

\section{Organizacijska učinkovitost in zadovoljstvo kupca}

V tem članku predstavljamo pomen součinkovanja med organizacijsko kulturo, ki predstavlja osrednji kazalec organizacijske učinkovitosti in zadovoljstvom kupca v dveh zdraviliščih v Sloveniji. Pri tem izhajamo iz podmene, da storitveni organizaciji dolgoročno uspešnost zagotavlja zlasti zadovoljstvo njenih kupcev. Namen naše študije je bil razkriti stališča zaposlenih in kupcev glede pomembnosti faktorjev organizacijske učinkovitosti pri posredovanju storitev $v$ organizacijskem okolju dveh slovenskih zdravilišč.

Izidi študije kažejo, da na organizacijsko učinkovitost storitev v procesu zadovoljevanja potreb kupca v obeh zdraviliščih, najbolj vplivajo zmogljivost zaposlenih, prilagodljivost in poslanstvo zdravilišča. Zaposleni $v$ zdraviliščih in kupci storitev $v$ zdraviliščih so si enotni glede učinka zmogljivosti zaposlenih pri posredovanju storitve, kar pa ne velja za druge faktorje, kjer se stališča obeh skupin v študiji razlikujejo med seboj. Izidi študije tudi kažejo, da kupci in zaposleni zadovoljstvo s storitvijo povezujejo z zmogljivostjo zaposlenih zadovoljevanju potreb kupca in s poslanstvom zdravilišča, ki se izraža v dolgoročnem odnosu do kupca. Kupci v obeh zdraviliščih so najbolj zadovoljni s standardnimi in preskušenimi storitvami, saj izidi študije kažejo, da inovacijski potencial, kot dimenzija organizacijske kulture zdravilišča, nima značilnega vpliva na zadovoljstvo kupca. Pri tem se stališča kupcev in zaposlenih razlikujejo glede na zdravilišče. Pomen naše študije je zlasti v ugotovitvi, da je učinkovita organizacija pomemben faktor zadovoljstva kupca še zlasti takrat, ko se zaposleni tega zavedajo in znajo in zmorejo zadovoljiti pričakovanja kupca.

Ključne besede: organizacijska učinkovitost, zadovoljstvo kupca, kompleksnost kupca, usmerjenost v storitve, preživetje, prilagodljivost 